\title{
Implication of the mineralocorticoid axis in rainbow trout osmoregulation during salinity acclimation
}

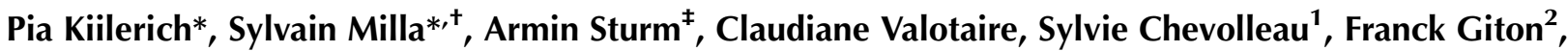 \\ Xavier Terrien, Jean Fiet ${ }^{2}$, Alexis Fostier, Laurent Debrauwer ${ }^{1}$ and Patrick Prunet \\ INRA-SCRIBE, IFR 140, Campus de Beaulieu, 35042 Rennes cedex, France \\ ${ }^{1}$ UMR1089 Xénobiotiques, INRA-ENVT, BP 93173, F-31027 Toulouse cedex 3, France \\ ${ }^{2}$ AP-HP CIB GHU Sud Henri Mondor, Faculté de Médecine, 94010 Créteil cedex, France \\ (Correspondence should be addressed to P Prunet; Email: patrick.prunet@rennes.inra.fr) \\ *(P Kiilerich and S Milla contributed equally to this work) \\ ${ }^{\dagger}$ (S Milla is now at University of Namur, Unit of Research in Organismal Biology, B-5000 Namur, Belgium) \\ ${ }^{\ddagger}$ (A Sturm is now at Institute of Aquaculture, University of Stirling, Stirling, UK)
}

\begin{abstract}
Cortisol and glucocorticoid receptors (GRs) play an important role in fish osmoregulation, whereas the involvement of the mineralocorticoid receptor (MR) and its putative ligand 11-deoxycorticosterone (DOC) is poorly investigated. In this study, we assessed the implication of DOC and MR in rainbow trout (Oncorhynchus mykiss) osmoregulation during hypo- and hypersaline acclimation in parallel with the cortisol-GR system. A RIA for DOC was developed to measure plasma DOC levels, and a MR-specific antibody was developed to localize MR protein in the gill, intestine, and kidney. This is the first study to report DOC plasma levels during salinity change and MR localization in fish osmoregulatory tissue. Corticosteroid receptor mRNA abundance was investigated in osmoregulatory tissue during salinity acclimation, and the effect of cortisol and DOC on
\end{abstract}

ionic transporters gene expression was assayed using an in vitro gill incubation method. Differential tissue-, salinity-, and time-dependent changes in $M R$ mRNA levels during both hyper- and hyposaline acclimations and the ubiquitous localization of $\mathrm{MR}$ in osmoregulatory tissue suggest a role for the MR in osmoregulation. Presumably, DOC does not act as ligand for $\mathrm{MR}$ in osmoregulation because there were no changes in plasma DOC levels during either freshwaterseawater (FW-SW) or SW-FW acclimation or any effect of DOC on gill ionic transporter mRNA levels in the gill. Taken together, these results suggest a role for MR, but not for DOC, in osmoregulation and confirm the importance of cortisol as a major endocrine regulator of trout osmoregulation.

Journal of Endocrinology (2011) 209, 221-235

\section{Introduction}

In mammals, the main mineralocorticoid hormone, aldosterone, plays a central role in the control of water and sodium homeostasis. Fish lack aldosterone because of their inability to synthesize this steroid (Jiang et al. 1998), but they have the ability to produce 11-deoxycorticosterone (DOC; Jiang et al. 1998) an intermediate of mammalian aldosterone synthesis. Recently, a mineralocorticoid receptor (MR) with high affinity for DOC has been characterized in rainbow trout (Oncorhynchus mykiss; Sturm et al. 2005) and in several other fish species (Greenwood et al. 2003, Kiilerich et al. 2007a, Stolte et al. 2008). The recent discovery of MR and its high affinity mineralocorticoid-like ligand (DOC) suggest the presence of a functional mineralocorticoid signaling axis in fish (Sturm et al. 2005). In this context, the corticosteroid signaling system in most fish consists of MR, DOC, and the glucocorticoid receptor isoforms, GR1 and GR2, along with their highaffinity ligand, cortisol. Moreover, cortisol activates not only the GRs but also the MR, thus cortisol has the potential to be a physiological ligand of both the glucocorticoid and the mineralocorticoid signaling systems.

As DOC is a specific ligand for MR and a tenfold more potent agonist compared with cortisol, this hormone could be the primary physiological agonist of the MR (Sturm et al. 2005) despite lower plasma levels of DOC compared with cortisol (Prunet et al. 2006). In fact, DOC has been detected in fish plasma at concentrations sufficient to activate the rtMR during specific physiological circumstances such as reproduction (Katz \& Eckstein 1974, Campbell et al. 1976, 1980, Truscott et al. 1978), where an observed 10- to 50-fold increase in plasma DOC levels in mature trout males compared with immature fish suggests a physiological role of this hormone (Milla et al. 2008). Taken together, this 
suggests the presence of a functional mineralocorticoid signaling axis in fish; however it remains to be known whether cortisol, DOC, or both serve as the physiological relevant agonist(s).

The main organ involved in the maintenance of hydromineral homeostasis in fish is the gill, in association with the posterior kidney and the intestine. Ion transporters serve to regulate $\mathrm{Na}^{+}$and $\mathrm{Cl}^{-}$flow over the gill epithelia. $\mathrm{Na}^{+}, \mathrm{K}^{+}{ }_{-}$ ATPase $\alpha 1 \mathrm{~b} ; \mathrm{Na}^{+}, \mathrm{K}^{+}, 2 \mathrm{Cl}^{-}$co-transporter (NKCC); and cystic fibrosis transmembrane conductance regulator (CFTR) are involved in ion secretion to counterbalance passive ion uptake in hyperosmotic environment (Marshall \& Grosell 2006), whereas V-type $\mathrm{H}^{+}$-ATPase; epithelium $\mathrm{Ca}^{2+}$ channel $(\mathrm{ECaC}) ; \mathrm{Na}^{+}-\mathrm{HCO}_{3}^{-}$cotransporter (NBC); $\mathrm{Na}^{+}$, $\mathrm{K}^{+}$-ATPase $\alpha 1 \mathrm{a}$; and carbonic anhydrase (CA) govern ion uptake in hypoosmotic medium (Marshall \& Grosell 2006, Parks et al. 2006, Perry \& Gilmour 2006). Cortisol represents a major endocrine actor in the regulation of ionic homeostasis, particularly after environmental salinity change, by regulating some of these seawater-/freshwater- (FW) specific ion transporters (McCormick 2001, Kiilerich et al. 2007b). The GRs are most likely taking part in some of these osmoregulatory effects due to the positive correlation between cortisol receptor concentration and $\mathrm{Na}^{+}, \mathrm{K}^{+}$-ATPase activity responsiveness to cortisol in the gill (Shrimpton \& McCormick 1999, McCormick 2001) and the inhibitory effects of the GR-specific antagonist, RU486 (Kiilerich et al. 2007 a, McCormick et al. 2008). In contrast, information on the role of DOC and MR in fish osmoregulation is very limited. DOC administration promoted renal salt retention but branchial salt loss in rainbow trout (Holmes 1959), but McCormick et al. (2008) showed no effect of DOC on gill $\mathrm{Na}^{+}, \mathrm{K}^{+}$-ATPase activity; $\alpha 1 \mathrm{a}, \alpha 1 \mathrm{~b}$ mRNA expression; or overall salinity tolerance during Atlantic salmon (Salmo salar) seawater (SW) adaptation. Likewise, no effect of the specific $\mathrm{MR}$ antagonist, spironolactone, on cortisol stimulation of gill $\mathrm{Na}^{+}, \mathrm{K}^{+}$-ATPase activity or $\alpha 1 \mathrm{a}, \alpha 1 \mathrm{~b}$ expression was observed (McCormick et al. 2008). However, Kiilerich et al. (2011) have recently shown a seasonal dependent effect of DOC on ion transporter mRNAs in Atlantic salmon gill tissue explants. Furthermore, a role for MR in FW acclimation has been suggested on the basis of the inhibitory effects on some gill osmoregulatory parameters in rainbow trout and killifish (Fundulus heteroclitus; Sloman et al. 2001, Scott et al. 2005).

Thus, although cortisol-GRs are considered an important SW-/FW-adapting endocrine system, the exact role of DOC-MR in fish osmoregulation remains unclear. To assess this question, we compared the regulation of DOC-MR in parallel with that of cortisol-GRs in salinity adaptation of rainbow trout. Regulation of plasma cortisol and DOC levels during FW-SW and SW-FW adaptations and regulation of $M R, G R 1, G R 2$ mRNA expression in osmoregulatory tissue (gill, posterior kidney, and intestine) were investigated. Furthermore localization of GR 1 and MR in these tissues was investigated and co-localized with the $\mathrm{Na}^{+}, \mathrm{K}^{+}$-ATPase protein. Finally, an in vitro gill block incubation system was used to investigate cortisol and DOC regulation of important ion transporters in the gill.

\section{Materials and Methods}

\section{Fish and salinity transfer}

Investigations and animal care were conducted according to the guiding principles for the use and care of laboratory animals in compliance with French and European regulations on animal welfare. Immature rainbow trout (O. mykiss) were obtained from INRA/PEIMA fish farm (Sizun, France) and were maintained under natural photoperiod in a re-circulated water system at $12{ }^{\circ} \mathrm{C}$ at the INRA/SCRIBE experimental facilities (Rennes, France).

The immature rainbow trout $(89 \pm 18 \mathrm{~g}$, mean \pm s.D. $)$ were randomly distributed in two $1 \mathrm{~m}^{3}$ tanks (with 70 trout in each tank) containing either FW or synthetic 30\% SW (Instant Ocean, Aquarium Systems, Mentor, OH, USA) 2 weeks before the start of the experiment. Before the start of the experiment, six fish from each salinity were sampled to constitute either the FW or the SW initial control group. FW-acclimated fish were transferred to two tanks containing either FW (FW-FW controls) or SW (FW-SW group), and vice versa for the SW-acclimated fish (SW-SW controls and SW-FW group). Such protocol allowed to leave each tank untouched during at least $24 \mathrm{~h}$ to avoid confounding effects due to sampling stress. No mortality was observed during the osmotic challenges. FW-SW-transferred fish were sampled at $12 \mathrm{~h}$, and $1,2,5,9$, and 21 days post-transfer and SW-FWtransferred fish were sampled at $6 \mathrm{~h}$, and 1, 2, 4, and 7 days post-transfer for plasma hormone measurements and the gill, intestine, and kidney RNA analysis $(n=6-8)$. Fish were killed with 2-phenoxyethanol; blood was withdrawn with a heparinized syringe, followed by cutting of the spine and pithing the brain. Blood was kept on ice until plasma was separated by centrifugation and frozen at $-80{ }^{\circ} \mathrm{C}$ until hormone analysis. The gill, posterior kidney, and intestine were dissected out, snap-frozen in liquid $\mathrm{N}_{2}$, and kept at $-80{ }^{\circ} \mathrm{C}$ until RNA analysis.

\section{Plasma cortisol measurements}

Cortisol measurements were carried out using a RIA procedure described previously (Auperin et al. 1997).

\section{Plasma DOC measurements}

Fluoroimmunoassay A fluoroimmunoassay (FIA), adapted from a testosterone FIA (Fiet et al. 2004) with minor modifications, was developed for plasma DOC measurements: a rabbit anti-DOC antibody (Fiet 1979) was used, DOC was extracted from $1.5 \mathrm{ml}$ plasma using cyclohexane/ethyl acetate $(1 / 1, v / v)$, and DOC loss during extraction and HPLC was 
monitored using 2000 d.p.m. tritiated DOC. The amounts of DOC added to the wells of the microtiter plates to establish the standard curve were in pg/well: 400, 200, 100, 50, 25, 12.5, $6 \cdot 25,3 \cdot 12,1 \cdot 56,0 \cdot 78$, and $0 \cdot 39$. This FIA assay was used to validate the specificity of the anti-DOC antibody and to validate the absolute levels of DOC measured in plasma samples by mass spectrometry (MS) (see below).

Validation of the anti-DOC antibody specificity by cross-reactivity test The specificity of the anti-DOC antibody was assessed by testing the cross-reactivity of the antibody with a panel of fish steroids as described in Fiet et al. (2004) complemented with cortisone and the piscine sex steroid 17,20 $\beta$-dihydroxy-4-pregnen-3-one (17 $\alpha, 20 \beta$ dihydroxyprogesterone). No steroids had a cross-reactivity higher than $3.5 \%$, and cortisol, the most abundant corticosteroid in fish, presented a cross-reactivity lower than $0 \cdot 01 \%$.

\section{Validation of measurements of absolute DOC levels} using MS Liquid chromatography (LC) coupled to MS was used to validate the measured levels by the FIA for DOC by determining the amount of DOC in 15 plasma samples. The LC separation was achieved on a Surveyor (Thermo Fisher, Les Ulis, France) HPLC system fitted with a C18 Purospher Star column $(50 \times 2 \mathrm{~mm}, 3 \mu \mathrm{m})$. The following gradient elution was used (flow rate, $0.2 \mathrm{ml} / \mathrm{min}$ ): $0 \mathrm{~min}, 50 \% \mathrm{~B}$, from 0 to $10 \mathrm{~min}$, linear gradient from 50 to $100 \% \mathrm{~B}$, then $100 \% \mathrm{~B}$ from 10 to $15 \mathrm{~min}$, with $\mathrm{A}=\mathrm{H}_{2} \mathrm{O} /$ methanol/acetic acid $(90 / 10 / 0 \cdot 2, \mathrm{v} / \mathrm{v} / \mathrm{v})$ and $\mathrm{B}=\mathrm{H}_{2} \mathrm{O} /$ methanol/acetic acid $(10 / 90 / 0 \cdot 2, \mathrm{v} / \mathrm{v} / \mathrm{v})$. Mass spectrometric acquisition was carried out on a triple quadrupole mass spectrometer (TSQ Quantum Discovery, Thermo Fisher) fitted with an electrospray ionization source operated in the positive ionization mode. Typical ionization source operating conditions were as follows: electrospray needle, $5 \mathrm{kV}$; heated transfer capillary temperature, $350^{\circ} \mathrm{C}$; heated transfer capillary voltage, $35 \mathrm{~V}$; and tube lens offset, $87 \mathrm{~V}$. The detection and quantification of DOC was based on the monitoring of two MS/MS diagnostic transitions, i.e. $m / z 331 \rightarrow 109$ and $m / z 331 \rightarrow 97$, using a collision energy of $39 \mathrm{eV}$. The calibration curve was established from four standard DOC solutions at 1, 10, 50, and $100 \mathrm{pg} / \mu \mathrm{l}$ respectively (injected volume $10 \mu \mathrm{l}$ ). Linearity was checked between 1 and $100 \mathrm{pg} / \mu \mathrm{l}\left(R^{2}=0 \cdot 9993\right)$. Detection limits and quantification limits were reached at $0 \cdot 1 \mathrm{pg} / \mu \mathrm{l}$ $(S / N=3)$ and $0.5 \mathrm{pg} / \mu \mathrm{l}(S / N=10)$ respectively. Repeatability was assessed by triplicate injections of the standard DOC solutions. The resulting residual standard deviations (RSDs) were in the range of 2-5\%. Matrix effects were checked from spiked plasma extracts.

RIA To have an in-house DOC assay to measure plasma DOC levels routinely, the FIA, as described above, was modified to RIA using the same anti-DOC antibody. To estimate the DOC loss during extraction and HPLC before the immunoassay, 2000 d.p.m. of an ethanolic tritiated deoxycorticosterone solution (American Radiolabeled
Chemicals, St Louis, MO, USA) were added to $1.5 \mathrm{ml}$ of each plasma sample in $15 \mathrm{ml}$ borosilicate glass tubes. After steroid extraction with $2 \mathrm{ml}$ cyclohexane/ethyl acetate (1/1, $\mathrm{v} / \mathrm{v})$ two times, the organic phase was evaporated to dryness and steroids were re-dissolved in $65 \mu$ ethanol. Before HPLC of plasma samples, $50 \mu \mathrm{l}$ ethanolic tritiated DOC (2000 c.p.m.) were loaded on the column to determine the HPLC fraction containing DOC (normally between 2.5 and $3.5 \mathrm{~min}$ after injection), and samples were collected $20 \mathrm{~s}$ before and $40 \mathrm{~s}$ after this peak. Ethanolic plasma steroid extracts $(50 \mu \mathrm{l})$ were then injected in a ZORBAX SB-C18 HPLC column (Agilent, Massy, France) and passed through a mobile phase containing acetonitrile/water $(80 / 20, \mathrm{v} / \mathrm{v})$ acidified with $0 \cdot 01 \%$ sulfuric acid. The organic chromatographic elution fractions were evaporated to dryness and re-dissolved in $250 \mu \mathrm{l}$ assay buffer (see Fiet et al. 2004). For RIA, $100 \mu \mathrm{l}$ sample (measured in duplicates) or DOC standards (measured in triplicates) were incubated for $2.5 \mathrm{~h}$ at $4{ }^{\circ} \mathrm{C}$ with $100 \mu \mathrm{l}$ rabbit anti-DOC antibody (Fiet 1979) followed by incubation for $3 \mathrm{~h}$ at $4{ }^{\circ} \mathrm{C}$ with 18000 c.p.m. $\left[{ }^{3} \mathrm{H}\right]$-DOC tracer, $100 \mu \mathrm{l}$ anti-rabbit scintillation proximity assay reagent (Bosworth \& Towers 1989). Samples were then precipitated with $25 \%$ polyethylene glycol 6000 over night, after which the pellet was re-dissolved in $100 \mu \mathrm{l}$ ethanol and mixed with $2.5 \mathrm{ml}$ Insta-Fluor (Perkin-Elmer, Waltham, MA, USA) before counting on a Packard Tri-Carb 2100 TR $\beta$-ray counter. A DOC standard curve was routinely carried out with $7 \cdot 8,15 \cdot 6,31 \cdot 2,62 \cdot 5,125,250,500,1000,2000,4000$, and $8000 \mathrm{pg} / \mathrm{ml}$.

The validity of the RIA was evaluated using a surcharge test, where six aliquots of $50 \mu \mathrm{l}$ plasma were loaded with $50 \mu \mathrm{l}$ of known quantities of DOC (final concentrations: 31, 62, 125, 250 , and $500 \mathrm{pg} / \mathrm{ml}$ ). Mean recoveries ranged from 83 to $123 \%$ dependent on the dose. A standard curve of DOC $(1 \cdot 9,3 \cdot 9,7 \cdot 8$, $15 \cdot 6,31 \cdot 2,62 \cdot 5,125,250,500,1000,2000,4000$, and $8000 \mathrm{pg} / \mathrm{ml}$ ) was included to assess the lower and upper detection limits of the assay. Finally, the inter-assay variability was assessed by quantifying DOC levels in triplicates in 14 different assays for three samples $(7 \cdot 8,125$, and $2000 \mathrm{pg} / \mathrm{ml}$ respectively) and the intra-assay variability was assessed by measuring the $\mathrm{B}_{0}$ (containing gelatine buffer, anti-DOC antibody, and $\left[{ }^{3} \mathrm{H}\right]-\mathrm{DOC}$ tracer only) ten times in the same assay.

\section{Immunohistochemistry}

Antibodies GR1 localization studies were conducted using a GR1-specific rabbit polyclonal antibody developed against the N-terminal portion of rainbow trout GR1 (Tujague et al. 1998). Localization of mitochondria-rich cells by means of $\mathrm{Na}^{+}, \mathrm{K}^{+}$-ATPase was carried out with a monoclonal antibody raised against the $\alpha 1$ subunit of avian $\mathrm{Na}^{+}, \mathrm{K}^{+}$ ATPase (anti-Na ${ }^{+}, \mathrm{K}^{+}$-ATPase $\alpha 5$ antibody) developed by Douglas M Fambrough and obtained from the Developmental Studies Hybridoma Bank developed under the auspices of the NICHD and maintained by the University of Iowa (Department of Biological Sciences, Iowa City, IA 
52242, USA). For localization of MR, a rabbit polyclonal antibody against the rainbow trout $\mathrm{MR}-\mathrm{AB}$ domain was developed in the laboratory using a rainbow trout $\mathrm{MR}-\mathrm{AB}$ domain-GST fusion protein (from now on called MR-GST) for immunization (Milla et al. 2008).

Validation of anti-MR antibody by immunoneutralization Recombinant MR-GST fusion protein used for immunization of rabbits and GST alone (to serve as control) was amplified in Escherichia coli in $2 \times$ YTA medium (per liter $2 \times$ YTA medium: $16 \mathrm{~g}$ tryptone, $10 \mathrm{~g}$ yeast extract, and $5 \mathrm{~g}$ $\mathrm{NaCl}$ ) with $100 \mu \mathrm{g} / \mathrm{ml}$ ampicillin at $37^{\circ} \mathrm{C}$ with shaking. Protein production was induced with $1 \mathrm{mM}$ isopropyl $\beta$-D-1thiogalactopyranoside when $\mathrm{OD}_{600}$ of the bacterial culture reached $0 \cdot 6$. Cells were harvested $2 \mathrm{~h}$ later, and sonicated, and the bacterial pellet was discarded before GST purification. MR-GST or GST alone was incubated with glutathionesepharose $4 \mathrm{~B}$ resin for $30 \mathrm{~min}$ at $4{ }^{\circ} \mathrm{C}$, before washing two times with wash buffer 1 (PBS, $1 \mathrm{mM}$ EDTA, $1 \mathrm{mM}$ dithiothreitol (DTT), and $2 \mathrm{mM} \mathrm{NaCl}$ ) and one time with wash buffer 2 (PBS, $1 \mathrm{mM}$ EDTA, and $1 \mathrm{mM}$ DTT). MR-GST or GST was eluted for $30 \mathrm{~min}$ at $4{ }^{\circ} \mathrm{C}$ with $2 \mathrm{mM}$ glutathione in $50 \mathrm{mM}$ Tris- $\mathrm{HCl}$. A denaturing SDS gel was run to verify the correct size of the purified MR-GST. Western blot was conducted in order to assess the specificity of the anti-rtMR antibody for MR, showing one single band for purified MR-GST and no bands for the GST protein alone. Immunoneutralization of anti-MR-AB domain antibody was carried out as described below (section Immunohistochemical localization of GR1 and MR in osmoregulatory tissue) except for $1 \mathrm{~h}$ incubation at room temperature of the antibody with graded doses of MR-GST or GST before incubation on the gill sections.

Immunohistochemical localization of GR1 and MR in osmoregulatory tissue One gill arch, a piece of the posterior kidney or $0.5 \mathrm{~cm}$ anterior and posterior intestine from three immature FW-adapted rainbow trout were excised and stored in $4 \%$ paraformaldehyde over night, dehydrated and embedded in paraffin. The tissues were sectioned $(5 \mu \mathrm{m})$, mounted on polylysine slides, deparaffinated, and hydrated. Sections were de-masked for a total of $3 \times 5 \mathrm{~min}$ in a microwave oven in $0.007 \mathrm{M}$ citrate, $\mathrm{pH}=6$, washed in $0.01 \mathrm{M}$ PBS $+1 \%$ Tween 20, and target protein was visualized using an Ultra Vision Anti-polyvalent, HRP/3,3'-diaminobenzidine (DAB) ready-to-use kit (Lab Vision Corporation, Thermo Fisher Scientific, Freemont, CA, USA) according to the manufacturer's recommendations. Briefly, sections were incubated for 10-15 min with hydrogen peroxide block, washed two times in PBS+ Tween 20, incubated for 5-10 min in Ultra V block and washed in PBS before incubation at room temperature for $1 \mathrm{~h}$ with primary antibody (mouse anti-GR1 (dilution 1:1250), mouse anti-MR (dilution 1:1500), mouse anti- $\mathrm{Na}^{+}, \mathrm{K}^{+}{ }_{-}$ ATPase (dilution 1:200), normal (pre-immune) rabbit serum (dilution 1:1500), or secondary antibody only (serving as control)). Thereafter the sections were washed four times in PBS + Tween 20, incubated $10 \mathrm{~min}$ with biotinylated goat anti-polyvalent rabbit antibody, washed 4 times, incubated for 10 min with streptavidin peroxidase, and washed four times. The chromogen DAB was used for visualization of antigens according to the manufacturers recommendations.

In vitro gill block incubation

All the gill arches were dissected from six FW-acclimated fish, and the cartilage was removed. Small pieces of gill (blocks of six filaments) were cut out, washed and incubated $1-2 \mathrm{~h}$ in pre-incubation medium (MEM (Sigma) with $25 \mathrm{mM}$ HEPES, $650 \mathrm{mg} / 1$ bicarbonate, $200 \mathrm{mM}$ glutamine, $5 \mathrm{mM}$ pyruvate, $100 \mathrm{U} / \mathrm{ml}$ penicillin, $50 \mu \mathrm{g} / \mathrm{ml}$ streptomycin, and $2.5 \mu \mathrm{g} / \mathrm{ml}$ amphotericin, $\mathrm{pH}=7 \cdot 55,300 \mathrm{mOsm})$. Subsequently, the gill filament blocks were distributed in a repeated measures design in 12-well culture plates $(\sim 10-12$ blocks of six filaments in each well) containing $2 \mathrm{ml}$ incubation medium (MEM with 4\% fetal bovine serum, $25 \mathrm{mM}$ HEPES, $650 \mathrm{mg} / \mathrm{l}$ bicarbonate, $200 \mathrm{mM}$ glutamine, $5 \mathrm{mM}$ pyruvate, $50 \mathrm{U} / \mathrm{ml}$ penicillin, $25 \mu \mathrm{g} / \mathrm{ml}$ streptomycin, and $6.25 \mu \mathrm{g} / \mathrm{ml}$ amphotericin, $\mathrm{pH}=7 \cdot 55,300 \mathrm{mOsm}$ ) and were incubated with hormones for $24 \mathrm{~h}$ at $12{ }^{\circ} \mathrm{C}$ with gentle

Table 1 QPCR target genes, GenBank accession numbers and primer sequences

Target gene

rtGR1

$r t G R 2$

$r$ MMR

CFTR (Salmo salar)

NKCC (Salmo salar)

$r t \mathrm{Na}^{+}, \mathrm{K}^{+}$-ATPase $\alpha 1 \mathrm{a}$

$r t \mathrm{Na}^{+}, \mathrm{K}^{+}$-ATPase $\alpha 1 b$

$\mathrm{rtNaHCO}$

ECaC (Danio rerio)

$r \mathrm{rH}^{+}$-ATPase (V-type)

rtCarbonic anhydrase

$r t 18 S$
GenBank no.

Z54210

AY495372

AF209873

AF161070

NM_001123683

AY319391

AY319390

NM_001124325

AY383562

AF140022

NM_001124220

AF309412
Forward primer

CCATCGTCAAGCGGGAAGAG

CTCCGCTTTCTCCAGCAGCTA GAAACAGATGATCCGCGTGGT

CAAGGCCCGCATACTGCT

CGAGACCAAGGCATTCTACA

GCAGACGCCTCTCGGAATT

GGAAGACGCCTATAGCCAAA

GGGGAACGTGGCGCAAGTATA

ACTTGGTCAACCGCAGAAAG

ATGTGCTGCCCTCTCTGTCT

CAGTCTCCCATTGACATCGTA

CGGAGGTTCGAAGACGATCA
Reverse primer

GGAACTCCACGCTAAGGGATTTATTC

GTGAGCACCCCGTAGTGACAG

TGGATCAGGGTGATTTGGTCCT

GCAGTGGTTCCACTCTGTGTT

ATGTCTCCGTCCTTCCAGTC

CAATGAGAAAGATGATGGATG

CGATGAGGAAGATGACAGCTT

CCCATCCTCAAGTTCATCCCT

CAGATTCCACTTGAGCGTGA

CCAATGGCATAGCAGGCATA

CGTTGTCGTCGGTGTAGGT

TCGCTAGTTGGCATCGTTTATG 
Table 2 Specificity of the rabbit anti-11-deoxycorticosterone (DOC) antibody used in RIA. Cross-reactivity of the anti-DOC antibody with a selection of fish steroid hormones is given as a percentage of the DOC signal

\begin{tabular}{|c|c|c|c|}
\hline Steroid & $\begin{array}{l}\text { Cross- } \\
\text { reactivity } \\
(\%)\end{array}$ & Steroid & $\begin{array}{l}\text { Cross- } \\
\text { reactivity } \\
(\%)\end{array}$ \\
\hline DOC & 100 & Aldosterone & $<0 \cdot 01$ \\
\hline Progesterone & $3 \cdot 5$ & 17-Hydroxypregnenolone & $<0 \cdot 01$ \\
\hline Corticosterone & $1 \cdot 66$ & $\Delta 4$-Androsterone & $<0 \cdot 01$ \\
\hline 11-Deoxycortisol & $1 \cdot 25$ & Dehydroepiandrosterone & $<0 \cdot 01$ \\
\hline Pregnenolone & $0 \cdot 28$ & $\Delta 4$-Androstenedione & $<0 \cdot 01$ \\
\hline $\begin{array}{l}\text { 17-Hydroxypro- } \\
\text { gesterone }\end{array}$ & $0 \cdot 05$ & Testosterone & $<0 \cdot 01$ \\
\hline Cortisol & $<0 \cdot 01$ & Estradiol & $<0 \cdot 01$ \\
\hline
\end{tabular}

agitation. Hormone treatments (adjusted for total ethanol load) were as follows: control ( $2 \mu \mathrm{l}$ ethanol), cortisol (F) alone (1 or $10 \mu \mathrm{g} / \mathrm{ml}$ ) or together with the GR antagonist RU486 $(10 \mu \mathrm{g} / \mathrm{ml} \mathrm{F}+6 \mu \mathrm{g} / \mathrm{ml}$ RU486), RU486 alone $(6 \mu \mathrm{g} / \mathrm{ml})$, or DOC $(10,100$ or $1000 \mathrm{ng} / \mathrm{ml})$. Gill blocks were stored at $-80^{\circ} \mathrm{C}$ until RNA extraction. Cortisol and RU 10 and $6 \mu \mathrm{g} / \mathrm{ml}$ respectively were used to ensure equimolar concentrations $(28 \mu \mathrm{M})$ of agonist (cortisol) and antagonist (RU). Cortisol in the doses used in this study has previously been demonstrated to be necessary to evoke an effect on $\mathrm{Na}^{+}$, $\mathrm{K}^{+}$-ATPase activity and $\alpha 1$-isoforms transcriptional levels in salmonids in the same type of experiment (McCormick et al. 1991, Kiilerich et al. 2007a, 2011). The actual tissue and cellular level of cortisol in this gill block incubation experiment may be much lower than $10 \mu \mathrm{g} / \mathrm{ml}$, due to diffusion limitations caused by apical structure of the epithelial cells and mucus secretion by the gills during incubation.

Total RNA extraction, reverse transcription, and real-time PCR

RNA extraction from gill blocks, whole gill arches, posterior kidney and intestine was carried out using TRIzol (Invitrogen) as described previously (Milla et al. 2006). Likewise, reverse transcription and real-time PCR analyses were carried out on an iCycler IQ thermocycler (Bio-Rad Laboratories) as described previously (Milla et al. 2006). Relative expression levels of target gene mRNAs were calculated using the Pfaffl equation (Pfaff 2001) and normalized to $18 \mathrm{~S}$ rRNA. Primers were designed using rainbow trout sequences when available (denoted $\mathrm{rt}$ ) except $\mathrm{ECaC}$ (Danio rerio), NKCC, and CFTR (S. salar). Primer sequences and GenBank accession number are shown in Table 1. To compare the expression levels among the target genes, rtGR1, rtGR2, and $r t M R$, an absolute quantification was carried out. A dilution series of rainbow trout corticosteroid receptor containing plasmids (pCMV-rtGR1, -rtGR2, or -rtMR) from 0.01 attomole to 1 femtomole (corresponding to $6 \times 10^{6}-6 \times 10^{11}$ copies, considering the size of the receptor in question $(8.6 \mathrm{~kb}$ for pCMV-rtGR 1 and -rtMR and $7.5 \mathrm{~kb}$ for pCMV-rtGR2)) were subjected to
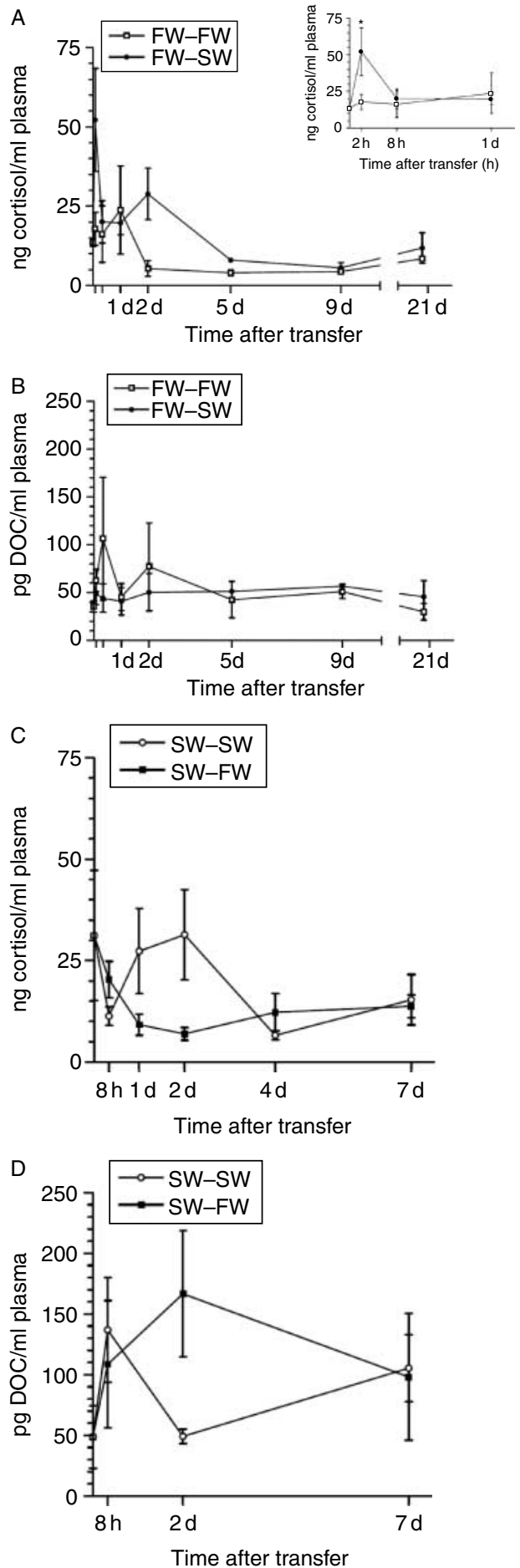

Figure 1 Variation in plasma cortisol (A and C) and DOC (B and D) during a FW-SW and a SW-FW acclimation time course. Open symbols denote control groups and black symbols denote transferred groups $(n=6-8)$. No overall effects of time and salinity transfer were detected with a two-way ANOVA. Significant differences between control and transferred fish are marked with a star $(P<0 \cdot 05)$. 
QPCR with specific primers. The resulting standard curves were fitted with regression lines and compared among primer sets to adjust for differences in QPCR efficiency due to differences in amplicon length and primer annealing and amplification efficiency. There were moderate differences in the absolute expression levels among the three primer sets (data not shown); thus, the expression levels of rtGR1, rtGR2, and rtMR in the gill, intestine, and kidney were adjusted accordingly to render a comparison of mRNA expression levels between receptors possible. Due to separate reverse transcription sessions for each tissue (gill, intestine, or kidney) at each transfer (FW-SW or SW-FW) - six in all - it is not possible to compare the expression level of corticosteroid receptors between tissues and salinity transfers.

\section{Statistical analysis}

All QPCR and plasma hormone data were analyzed using two-way ANOVA followed by Student's $t$-test. When necessary, data were transformed to obtain normality and homogeneity of variances. In vitro gill block incubation data were analyzed using a repeated-measures one-way ANOVA followed by multiple $t$-tests with Bonferroni's correction or, in case of non-normal distributed data sets, analyzed using a non-parametric Friedman test followed by Dunn's multiple comparison test (control column was compared with all treatment groups, and $10 \mathrm{~F}$ was compared with $1 \mathrm{~F}, 10$ $\mathrm{F}+\mathrm{RU}$, and RU alone). In all cases, a significance level of $\alpha=0.05$ was used. All tests were performed using Prism3.03 (GraphPad Software Incorporated, La Jolla, CA, USA).

\section{Results}

\section{Development and validation of a DOC RIA}

To measure trout DOC plasma levels during salinity acclimation, a FIA was developed using a rabbit anti-DOC antibody. Absolute FIA measurements of DOC levels were validated using MS (LC-MS-MS) with no significant difference in absolute DOC levels measured with FIA and MS (results not shown). The specificity of the antibody was validated by assessing the cross-reactivity with a panel of fish
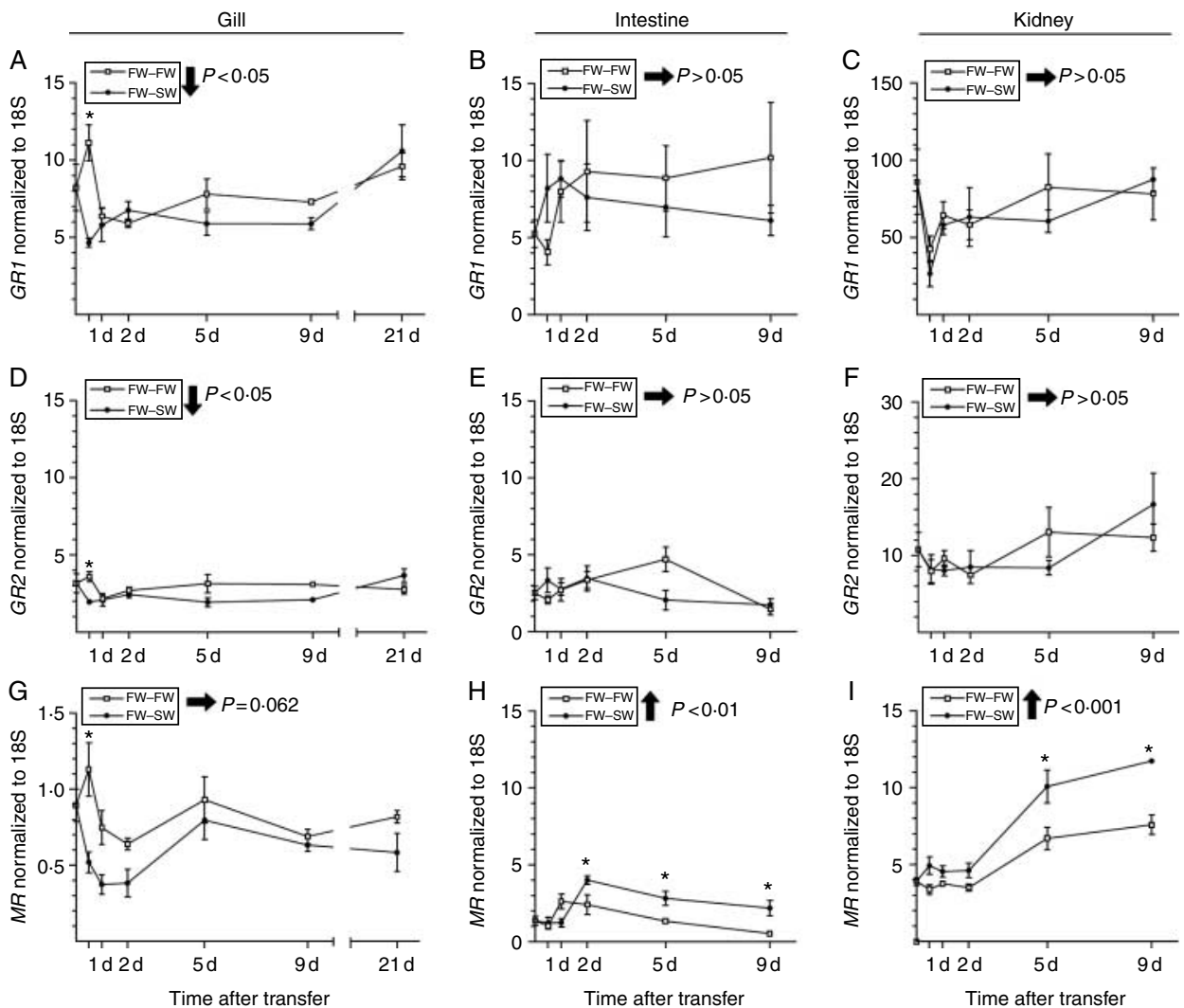

Figure 2 Variation in $G R 1(\mathrm{~A}-\mathrm{C}), G R 2(\mathrm{D}-\mathrm{F})$, and $M R(\mathrm{G}-\mathrm{l}) \mathrm{mRNA}$ levels in gill (left column), intestine (middle column) and kidney (right column) during a FW-SW acclimation time course. Open and filled symbols denote control and transferred groups respectively $(n=6-8)$. Overall effects of time and salinity transfer were detected with a two-way ANOVA and significant differences between control and transferred fish are marked with an asterisk $(P<0 \cdot 05)$. Solid arrows accompanied by a $P$ value indicate overall effect of salinity transfer and the direction of the movement in the transcript level. There was an overall effect of time in panels $A, C, E, F, G, H$, and I. 
steroids given in Table 2. The antibody did not show any significant cross-reactivity with other common fish steroid hormones (Table 2). To have an in-house DOC assay, the FIA was modified to a RIA using the same antibody and only exchanging the biotin-labeled DOC with radioactive labeled ${ }^{3} \mathrm{H}$-DOC. The repeatability of the RIA was assessed by calculation of the inter-assay variability coefficient $(13 \cdot 7$, $22 \cdot 5$, and $12 \cdot 9 \%$ for the doses 2000,125 , and $7 \cdot 8 \mathrm{pg} / \mathrm{ml}$ respectively) and the intra-assay variability coefficient $(6 \cdot 2 \%)$ and sensitivity was assessed by determination of the minimum detectable limit of DOC $(10 \mathrm{pg} / \mathrm{ml})$ with an $\mathrm{IC}_{50}$ estimated to $21 \mathrm{pg} /$ well (not shown).

Measurement of plasma cortisol and DOC levels following salinity changes

Apart from a significant increase in plasma cortisol levels $2 \mathrm{~h}$ after transfer from FW to SW (Fig. 1A, insert) neither salinity transfer gave rise to any overall changes in plasma cortisol (Fig. 1A $(P=0 \cdot 118)$, C $(P=0 \cdot 2298))$. Cortisol concentration in plasma fluctuates around $15-25 \mathrm{ng} / \mathrm{ml}$ plasma - 150-200 times higher than plasma DOC. There were no significant changes in DOC plasma levels after FW-SW $(P=0.4953)$, SW-FW $(P=0.5619)$, or control transfers, with DOC plasma levels fluctuating around $50-150 \mathrm{pg} / \mathrm{ml}$ regardless of acclimation salinity. Occasionally, DOC levels in plasma samples were lower than the detection limit in the RIA $(10 \mathrm{pg} / \mathrm{ml})$ resulting in the exclusion of two to three samples in some groups.

\section{Regulation of corticosteroid receptors in osmoregulatory tissue during salinity acclimation}

FW-SW transfer of rainbow trout resulted in an overall decrease in gill GR1 $(P<0 \cdot 05)$ and GR2 $(P<0 \cdot 05)$ mRNA levels, but not in $M R(P=0 \cdot 062)$ (Fig. $2 \mathrm{~A}, \mathrm{D}$, and $\mathrm{G})$. There is a significant difference between transferred and control fish $12 \mathrm{~h}$ post-transfer for all these transcripts, due to an increase in the control group concurrent with a decrease in the FW-SWtransferred group. Contrary to gill, MR is the only regulated
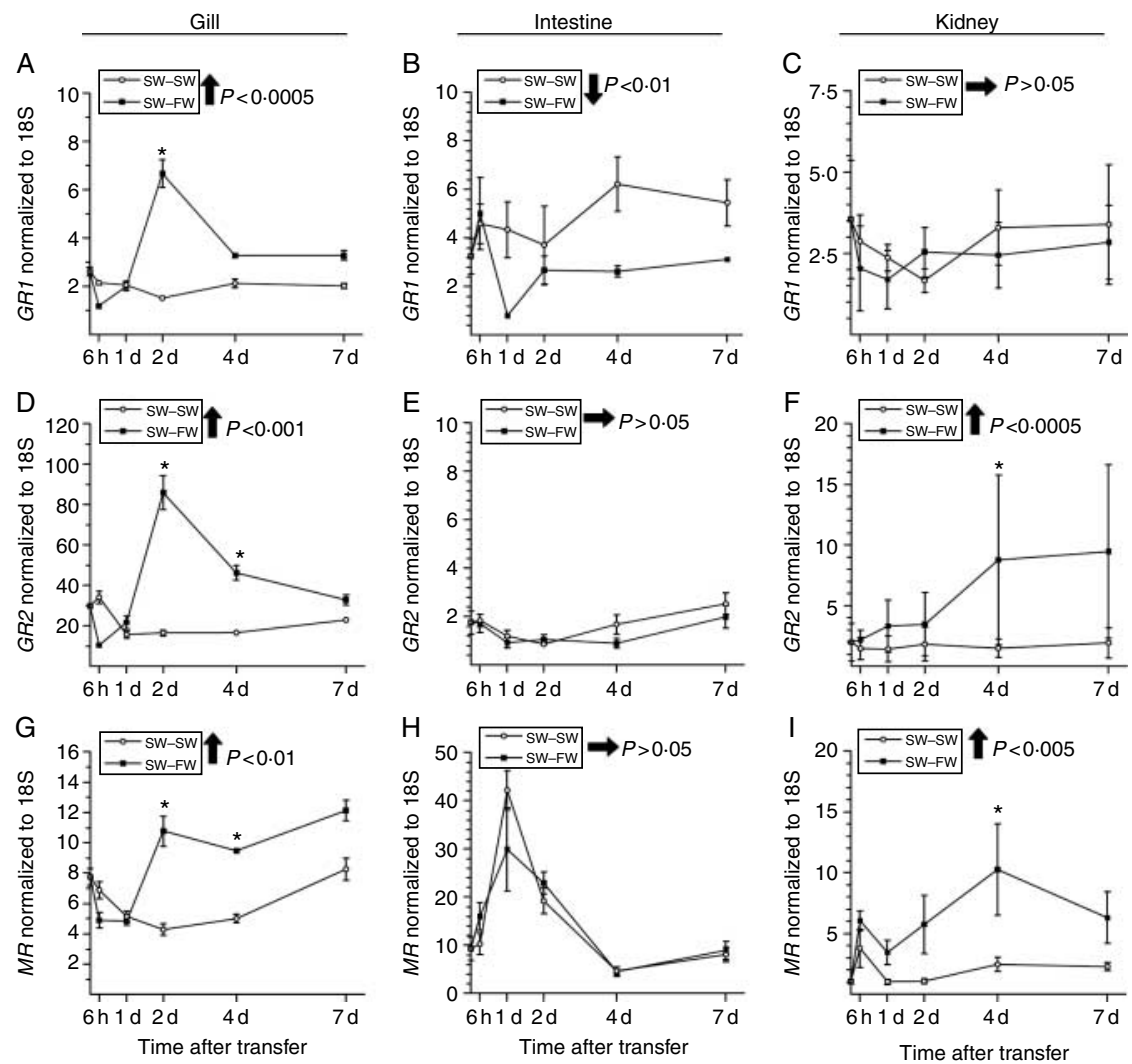

Figure 3 Variation in $G R 1(\mathrm{~A}-\mathrm{C}), G R 2(\mathrm{D}-\mathrm{F})$, and $M R(\mathrm{G}-\mathrm{l}) \mathrm{mRNA}$ levels in gill (left column), intestine (middle column) and kidney (right column) during a SW-FW acclimation time course. Open and filled symbols denote control and transferred groups respectively $(n=6-8)$. Overall effects of time and salinity transfer were detected with a two-way ANOVA, and significant differences between control and transferred fish are marked with an asterisk $(P<0 \cdot 05)$. Solid arrows accompanied by a $P$ value indicate overall effect of salinity transfer and the direction of the movement in the transcript level. There was an overall effect of time in panels $A, D, E, G, H$, and I. 
corticosteroid receptor during this FW-SW acclimation in the intestine and kidney. There is an overall increase in $M R$ mRNA levels in the intestine $(P<0 \cdot 01)$ and kidney $(P<0 \cdot 0001)$ compared with the control transfer. Corticosteroid transcription levels are shown as relative expression levels normalized to $18 \mathrm{~S}$ but are adjusted according to differences in the QPCR (due to differences in amplicon length, primer annealing, and amplification efficiency) among the target genes as determined by the absolute quantification and thus allow a comparison of expression levels among the target genes (but not among tissues). Accordingly, Fig. 2 shows that GR1 is the highest expressed followed by GR2 with $M R$ as the lowest expressed transcript in the tissues investigated in this study.

SW-FW transfer resulted in an overall increase in gill GR1 $(P<0 \cdot 0005)$, gill and kidney GR2 $(P<0 \cdot 001$ and $P<0 \cdot 0005$ respectively), and gill and kidney $\operatorname{MR~}(P<0 \cdot 01$ and $P<0.005$ respectively). An overall decrease in GR 1 in the intestine $(P<0 \cdot 01 ;$ Fig. 3) was observed. Significant differences between SW-SW and SW-FW transferred fish were observed at days 2 and 4 for gill GR2 and MR, whereas differences are only significant at day 2 for GR 1 in the gill and at day 4 for GR2 and MR in the kidney.

A summary of the overall effects of salinity transfer sorted by tissue is given in Fig. 4 .

\begin{tabular}{|c|c|c|c|}
\hline & & \\
\hline & & FW-SW & SW-FW \\
\hline \multirow{3}{*}{ Gill } & GR1 & & \\
\hline & GR2 & & \\
\hline & $M R$ & & \\
\hline \multirow{3}{*}{ Intestine } & GR1 & & \\
\hline & GR2 & & \\
\hline & $M R$ & & \\
\hline \multirow{3}{*}{ Kidney } & GR1 & & \\
\hline & GR2 & & \\
\hline & $M R$ & & \\
\hline
\end{tabular}

Figure 4 Summary of significant overall effects of salinity transfer on GR1, GR2 and MR transcript levels in gill, intestine, and kidney. Upward and downward arrows indicate up- or down-regulation of the transcript level $(P<0 \cdot 05)$, and horizontal arrows indicate no significant effect of salinity transfer $(P<0 \cdot 05)$.
Validation of the specificity of the anti-rtMR antibody

To investigate the cellular distribution of $\mathrm{MR}$ in osmoregulatory tissue by immunohistochemistry (IHC), we developed an anti-rtMR antibody using an rtMR-AB domain-GST fusion protein (GST-MR) as antigen. Initially, the specificity of the anti-MR antibody for rtMR over GST was validated using western blot producing only one single band for the GST-MR fusion protein and no bands for the GST protein alone (not shown). Unfortunately, when used with tissue protein extracts (gill, intestine, kidney, brain, and heart), the anti-MR antibody did not prove applicable to detect MR. The specificity of the MR antibody in IHC was validated by immunoneutralization of the MR antibody with the immunogenic protein for $1 \mathrm{~h}$ before IHC. As shown in Fig. 5, the recombinant fusion protein (MR-GST) drastically reduces the immunoreactivity of the $M R$ antibody (Fig. 5, compare panels A and B). Incubation of the gill tissue with MR-GST without MR antibody or pre-injection rabbit serum did not give rise to any artifacts (Fig. 5C and $\mathrm{G}$ respectively). The specificity of the rtGR1 antibody has previously been demonstrated in several studies (Teitsma et al. 1998, Tujague et al. 1998, Dang et al. 2000, 2001).

\section{Co-localization of corticosteroid receptors in osmoregulatory tissue}

In the gill, GR 1 is expressed in chloride cells and pavement cells, with an occasional expression in deeper lying cells not in direct contact with water (Fig. 5D). The $\mathrm{Na}^{+}, \mathrm{K}^{+}$-ATPase antibody was used to localize gill chloride cells in the interlamellar epithelia in these FW-acclimated fish (Fig. 5E). Although GR1 is localized in most chloride cells in the interlamellar space (white arrows), GR1 is also located in other cell types on the lamellae and in the interlamellar space (black arrows). MR is ubiquitous and evenly distributed in all cell types in the gill epithelium on the lamellae and in the interlamellar space except pillar cells (Fig. 5F), thus an extensively co-localization of MR and GR 1 can be observed in all the different gill cell types.

There is a high degree of co-localization of GR1 and MR throughout the columnar enterocytes in the anterior and posterior intestine (Fig. 6I, E, K, and G). Localization of the $\mathrm{Na}^{+}, \mathrm{K}^{+}$-ATPase protein indicates the basolateral membrane of the enterocytes in the intestine (Fig. 6F) as opposite to the apical brush border (Fig. 6J). Interestingly, MR staining is markedly more intense in the apical than in the basolateral part of the enterocytes.

$\mathrm{Na}^{+}, \mathrm{K}^{+}$-ATPase localization was employed to identify the different tubular cell types in the kidney showing mainly basolateral localization in proximal tubuli (marked with $\mathrm{P}$ ), homogenous localization throughout the cells of the distal tubuli (marked with D), and for the collecting duct cells a widespread localization with a more prominent expression localized at the basolateral part (marked with C; Fig. 6B). The GR1 protein is mostly observed in the basolateral part of the cytoplasm and in the cell nuclei of renal cells showing a non-homogenous 

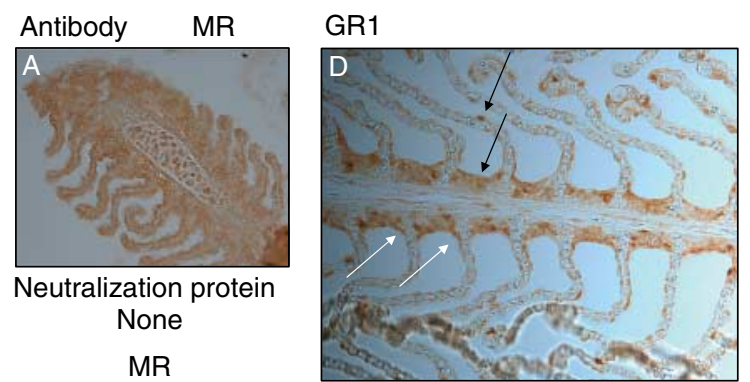

$\mathrm{Na}^{+}, \mathrm{K}^{+}$-ATPase
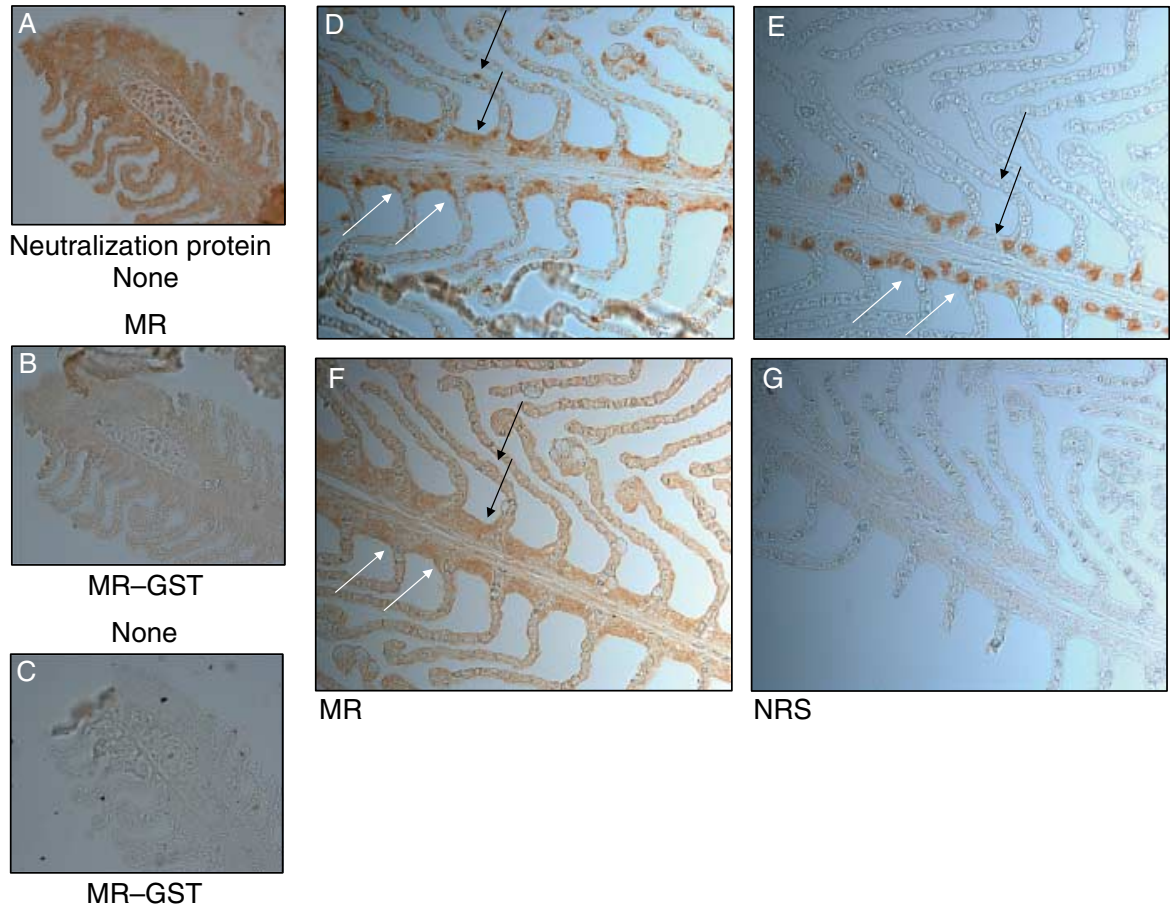

NRS

Figure 5 Validation of the anti-rtMR antibody and immunohistochemical localization of MR, GR1, and $\mathrm{Na}^{+}, \mathrm{K}^{+}$-ATPase in the gill. The specificity of the MR antibody was investigated using the MR-AB domain-GST fusion protein employed for immunization of rabbits. Coloration arising from MR localization (A) in the gill is completely competed away by the MR-GST fusion protein (B). The MR-GST fusion protein alone did not give rise to any coloration (C). Immunohistochemical localization of GR1 (D), Na ${ }^{+}, \mathrm{K}^{+}$-ATPase (E) and MR (F) in FW-adapted trout gill. Pre-immune rabbit serum was applied as control and did not result in any unspecific binding (G). Pavement and chloride cells in which GR1 and MR co-localize are shown with black and white arrows respectively. $40 \times$ magnification for panels $A-C$ and $20 \times$ magnification for panels D-G.

expression among the different renal cell types (Fig. 6A). MR-specific staining in the kidney is very weak (Fig. 6C) with no apparent difference between the different tubular cell types.

In vitro effects of cortisol and DOC in FW-acclimated fish gill

To investigate the possible physiological functionality of the proposed DOC-MR axis in osmoregulation, an in vitro incubation of gill blocks was conducted to compare the effects of DOC and cortisol on mRNA expression of important proteins associated with ion transport in the SW- and FW-type chloride cells. To reflect the physiological situation in trout, plasma DOC was used at the same or lower concentration than cortisol. There were no effects of any dose of DOC $(0 \cdot 01,0 \cdot 1$, or $1.0 \mu \mathrm{g} / \mathrm{ml})$ or the lower dose of cortisol $(1 \mu \mathrm{g} / \mathrm{ml})$ on transcript level of the osmoregulatory target genes selected in this study (Fig. 7). However, cortisol treatment at $10 \mu \mathrm{g} / \mathrm{ml}$ resulted in significant increases in the SW-associated target genes CFTR, NKCC, and $\mathrm{Na}^{+}, \mathrm{K}^{+}$-ATPase $\alpha 1 \mathrm{~b}$ (Fig. 7A-C) and the $\mathrm{FW}$-associated $\mathrm{Na}^{+}, \mathrm{K}^{+}$-ATPase $\alpha 1 \mathrm{a}, \mathrm{NBC}$, and $E C a C$ (Fig. 7D-F) transcript levels, but not in the FW-associated CA and $\mathrm{H}^{+}$-ATPase (Fig. $7 \mathrm{G}$ and $\mathrm{H}$ ).
Interestingly, when RU486, a validated antagonist for trout GR (Ducouret et al. 1995, Bury et al. 2003) was added to the $10 \mu \mathrm{g} / \mathrm{ml}$ cortisol treatment, we observed a significant inhibitory effect of the cortisol stimulation on CFTR, NKCC, $\mathrm{Na}^{+}-\mathrm{K}^{+}$-ATPase $\alpha 1$ a, and NBC gene expression. These results confirm the involvement of a GR-mediated cortisol signaling.

\section{Discussion}

The aim of this study was to clarify the osmoregulatory role of the DOC-MR axis in rainbow trout during FW-SW and SW-FW acclimation. The structural relationship between the tetrapod and teleost mineralocorticoid signaling axis naturally suggests a role in osmoregulation in fish, but this involvement has only been investigated rather poorly and punctuated. Although the osmoregulatory effect of cortisol is well established (see reviews McCormick 2001, Evans et al. 2005), the regulation of cortisol receptors in osmoregulatory tissues requires re-investigation after the relatively recent discovery of two GRs and the possibility that cortisol may be 

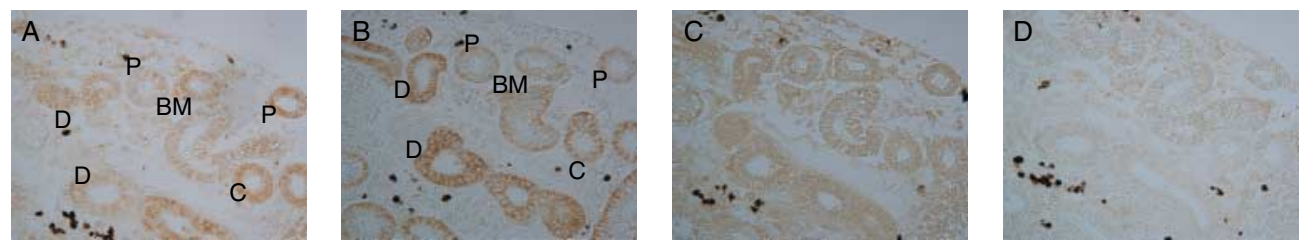

Posterior

kidney
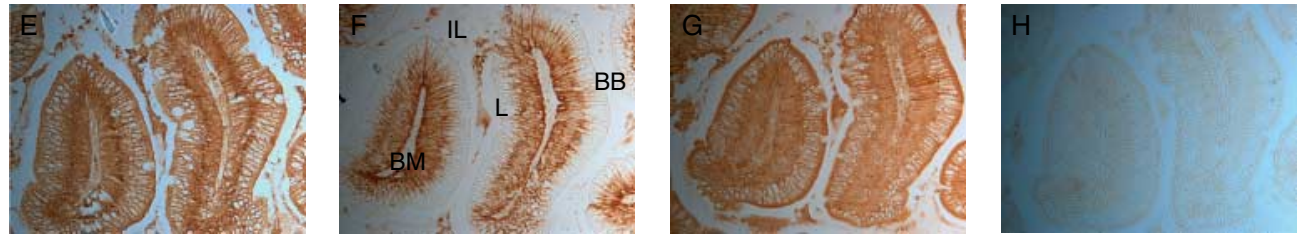

Posterior intestine
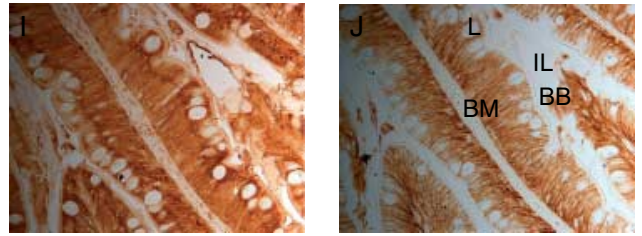

$\mathrm{Na}^{+}, \mathrm{K}^{+}$-ATPase

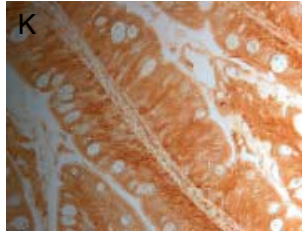

MR

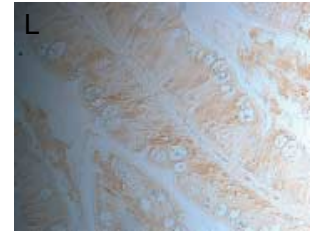

NRS

Figure 6 Immunohistochemical localization of GR1 (I, E, and A), $\mathrm{Na}^{+}, \mathrm{K}^{+}$-ATPase $(\mathrm{B}, \mathrm{F}$ and $\mathrm{J})$ and $\mathrm{MR}(\mathrm{C}, \mathrm{G}$ and $\mathrm{K})$ in anterior intestine (leftmost column), posterior intestine (middle column), and posterior kidney (rightmost column) in FW-adapted trout. Pre-immune rabbit serum was applied as control and did not result in any notable coloration (D, H and L). Magnification is $20 \times$ for all panels. Brush border (BB), intestinal lumen (IL), lipid droplet (L), basolateral membrane $(B M)$, collecting duct $(C)$, proximal tubulus $(P)$, and distal tubulus (D) are indicated on the $\mathrm{Na}^{+}, \mathrm{K}^{+}$-ATPase panels.

a physiological ligand for MR (Kiilerich et al. 2007a). In this context, we compare regulation of DOC and MR in osmoregulatory tissues (gill, intestine, and kidney) with that of cortisol and GR1/GR2, and compare cellular localization of MR and GR1 in these tissues. The data obtained in this study suggest involvement of MR but not of DOC in rainbow trout osmoregulation.

\section{Measurement of plasma DOC levels: is DOC an osmoregulatory hormone?}

In this study, measurement of plasma DOC levels by RIA has been carried out using an anti-DOC antibody after the specificity of the antibody was validated by analysis of crossreactivity with other structurally related steroids. Moreover, levels of DOC in different plasma samples measured using this antibody were also confirmed by MS analysis. Our assay allows us to detect as low level as $10 \mathrm{pg} \mathrm{DOC} / \mathrm{ml}$, which should lead to detection of any physiologically meaningful changes in plasma DOC levels. Using the RIA for DOC, we followed plasma levels after transfer of fish from FW to SW or the converse using a time-course design including time points ranging from a few hours to several days or weeks. In both experiments, we did not observe any significant changes related to salinity transfer or time. These results suggest that DOC is not a major osmoregulatory hormone involved in salinity acclimation in rainbow trout. This is in agreement with the lack of DOC effects on SW tolerance in vivo judged by gill $\mathrm{Na}^{+}, \mathrm{K}^{+}$-ATPase activity and gill mRNA levels of $\mathrm{Na}^{+}, \mathrm{K}^{+}$-ATPase $\alpha 1 \mathrm{a}$ and $\alpha 1 \mathrm{~b}$ in Atlantic salmon (McCormick et al. 2008) and no in vitro effect of DOC on gill ion transporter transcript levels (Fig. 6). However, a seasonal-dependent effect of DOC on Atlantic salmon gill $\mathrm{Na}^{+}, \mathrm{K}^{+}$-ATPase $\alpha 1 \mathrm{a}$ and $\alpha 1 \mathrm{~b}$ mRNA levels in vitro (Kiilerich et al. 2011) suggests that further investigations of the osmoregulatory potential of DOC are still necessary.

The lack of results of DOC treatment in this study is not due to an overall lack of responsiveness of the gill tissue, as cortisol treatment results in up-regulation of mRNAs from both SW- and FW-adaptive ion transporters as expected (Kiilerich et al. 2007a).

Despite this probable absence of DOC effect on salinity acclimation in salmonids, one should not conclude that DOC has no physiological role in salmonids. For example, a highly significant change in plasma DOC was observed during male and female trout reproduction suggesting a function for DOC in reproduction (Milla et al. 2008). Clearly, further studies on regulation of DOC plasma levels in fish during different physiological conditions would be helpful for our understanding of the function of DOC.

Regulation of MR in gill, intestine, and kidney during salinity acclimation: does MR have an osmoregulatory function in trout?

In this study, $M R$ mRNA levels in osmoregulatory tissues following salinity transfer (FW-SW and SW-FW) changed 

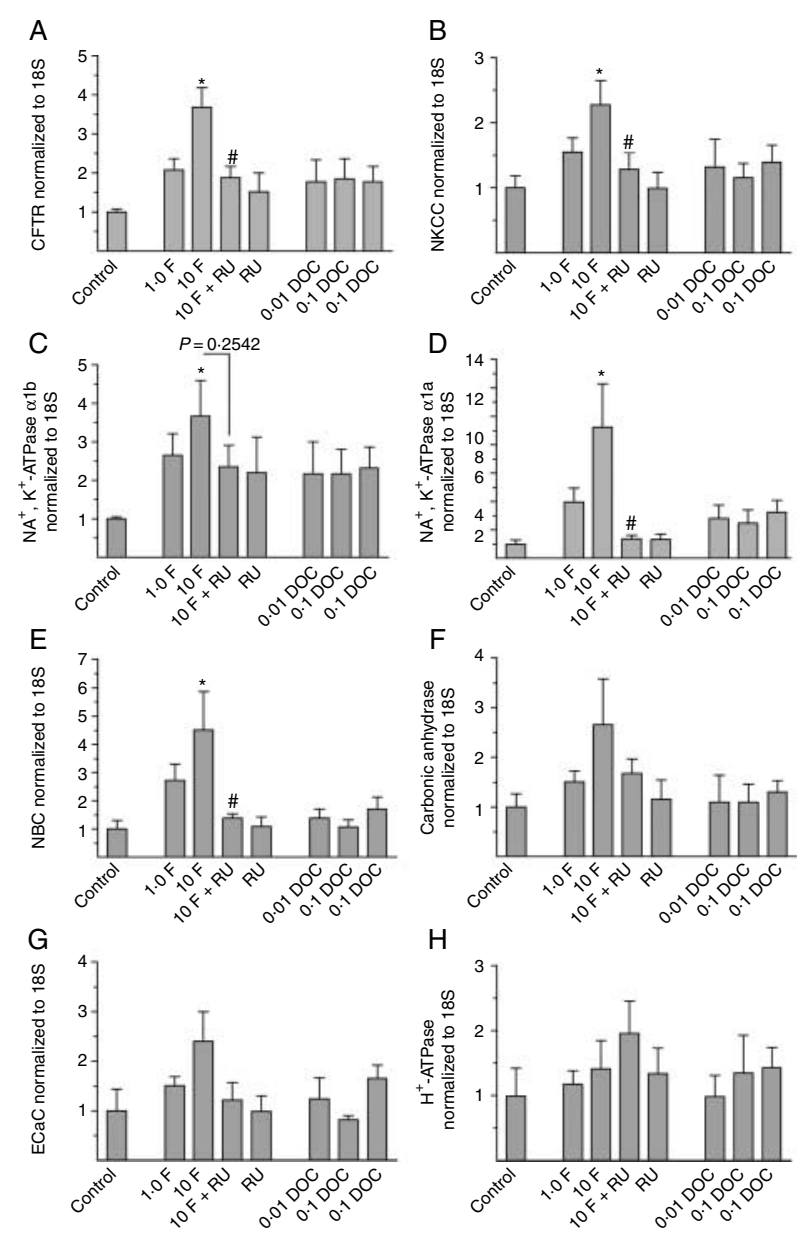

Figure 7 Effect of cortisol and DOC on selected ion transport protein mRNA levels in an in vitro gill block incubation. The three uppermost panels cystic fibrosis transmembrane conductance regulator (CFTR, A), $\mathrm{Na}^{+}, \mathrm{K}^{+}, 2 \mathrm{Cl}^{-}$co-transporter (NKCC, B), $\mathrm{Na}^{+}, \mathrm{K}^{+}$-ATPase $\alpha 1 \mathrm{~b}(\mathrm{C})$ represent $\mathrm{SW}$-acclimatory genes. $\mathrm{FW}$-acclimatory genes are represented by $\mathrm{Na}^{+}, \mathrm{K}^{+}$-ATPase $\alpha 1 \mathrm{a}$ (D), $\mathrm{Na}^{+}-\mathrm{HCO}_{3}^{-}$co-transporter (NBC, E), epithelial $\mathrm{Ca}^{++}$channel $(\mathrm{ECaC}, \mathrm{F})$, carbonic anhydrase $(\mathrm{CA}, \mathrm{G})$, and $\mathrm{H}^{+}$-ATPase $(\mathrm{H})$. Control levels are normalized to an arbitrary unit of 1 for each target gene $(n=6)$. Gill blocks were incubated with 1 and $10 \mu$ g cortisol $(1 \mathrm{~F}$ and $10 \mathrm{~F}$ respectively), $10 \mathrm{~F}+6 \mu \mathrm{g} / \mathrm{ml} \mathrm{RU} 486$ (10 F+ RU), RU468 alone (RU), $0 \cdot 01,0 \cdot 1$ or $1 \mu \mathrm{g} / \mathrm{ml}$ DOC $(0.01 \mathrm{D}, 0 \cdot 1 \mathrm{D}$ and $1.0 \mathrm{D}$ respectively). A repeated-measures one-way ANOVA followed by multiple $t$-tests with Bonferroni's correction (control column was compared to all treatment groups. $10 \mathrm{~F}$ was compared to $1 \mathrm{~F}, 10 \mathrm{~F}+$ RU and RU alone) was conducted for each target gene. Star denotes significant difference from control and denotes significant difference from $10 \mu \mathrm{g} / \mathrm{ml} \mathrm{F}$.

significantly in a tissue- and/or salinity-dependent manner. Such an extensive analysis of MR expression through a wide time-course study has never been carried out, and the observed changes suggest an osmoregulatory role of MR in relation to salinity. The differential regulation of $M R$ transcript levels shown in this study also suggests tissuespecific roles for MR in osmoregulation. Furthermore, the regulation might be of longer (intestine and kidney, FW-SW) or shorter (intestine, SW-FW) duration suggesting a dynamic role for MR.

During acclimation to hyperosmotic environment, this present study did not show any significant changes in $M R$ transcript level in the gill and thus does not straightforwardly suggest a role for MR in this situation. This is along the suggestion from Kiilerich et al. (2007b, unpublished data), where a down-regulation of MR in Atlantic salmon gill during FW-SW acclimation was observed. However, upregulation of MR during and after SW acclimation has also been reported (Nilsen et al. 2008, Yada et al. 2008), which suggests that the MR response may vary according to fish species and/or developmental status. Contrary to gill, an up-regulation of MR was observed in the kidney and intestine 2 days after transfer and onwards. Similar results have been reported by Yada et al. (2008) in the kidney of SW-adapted trout. This indicates an involvement of MR not only in the development of hypoosmoregulatory mechanisms in these tissues during acclimation to high salinity but also in the adapted fish, where MR might be a regulator of water/ion exchange mechanisms at the level of kidney and intestine.

Transfer of rainbow trout from SW to FW, which leads to development of hyperosmoregulatory mechanisms, is associated with significant increases in MR expression in the two main tissues involved in FW osmoregulation, gill and kidney (Fig. 3). This is in agreement with previous reports suggesting a role for MR in chloride cell proliferation and differentiation in FW-adapted rainbow trout and killifish (Sloman et al. 2001, Scott et al. 2005). Moreover, analysis of MR levels in the gill during Atlantic salmon smoltification lead Kiilerich et al. $(2007 a, b)$ to suggest that functionality of this receptor is coupled to hyper-osmoregulation.

Altogether, these data confirm the probable involvement of MR in osmoregulation. Further studies on MR in fish osmoregulatory tissue are now required to identify the molecular mechanisms concerning regulation of $\mathrm{MR}$ and MR signaling.

\section{Which ligand could be the main activator of the MR signaling pathway?}

Absence of changes in plasma DOC levels coincident with absence of DOC effects on gill gene expression in vitro, as shown in this study, raises the question regarding which corticosteroid hormone would activate the MR signaling pathway in response to salinity changes. In this study, measurement of plasma cortisol levels showed significant increase shortly after SW transfer which is in agreement with numerous previous similar studies carried out in salmonids (see review Mommsen et al. 1999). Furthermore, when compared with cortisol, plasma DOC levels are in general 150- to 200-fold lower. Although DOC activation of MR occurs at an only tenfold lower concentration than cortisol when tested in transfected COS cells (Sturm et al. 2005), the DOC plasma levels observed in this study do not favor a role 
for DOC as the activating ligand in the MR signaling system compared with cortisol. However, local concentrations of cortisol might be different from those in plasma, especially due to the activity of the $11 \beta$ HSD2 enzyme, which converts cortisol to receptor-inactive cortisone, and thus tentatively facilitates activation of MR signaling by DOC. This scheme is well known in mammals, where aldosterone is the activating ligand for the MR signaling system in distal nephrons of the kidney (Farman \& Rafestin-Oblin 2001, Rashid \& Lewis 2005). A functional $11 \beta \mathrm{HSD} 2$ enzyme was recently identified in rainbow trout (Jiang et al. 2003, Kusakabe et al. 2003) and changes in 11ßHSD2 mRNA levels in gill during salmonid salinity acclimation have been reported (Kiilerich et al. 2007b, Nilsen et al. 2008, Kiilerich et al. unpublished data).

Taken together, cortisol seems to be the most probable activator of the MR signaling pathway in rainbow trout exposed to salinity changes.

\section{Co-localization of MR and GR1 in the gill}

The co-localization of GR1 and MR with $\mathrm{Na}^{+}, \mathrm{K}^{+}{ }_{-}$ ATPase in gill chloride cells suggests a link between these corticoid receptors and osmoregulatory mechanisms. Interestingly, MR and GR are also localized in pavement cells, which also have been shown to have a function in osmoregulation (Marshall \& Grosell 2006). As a result, both GR1 and MR possess the potential to regulate physiological processes related to ion/water exchanges in the two cell types associated with osmoregulation in gill. The present localization pattern of GR1 that shows higher expression in chloride cells than in pavement cells is in good agreement with previous IHC studies in other salmonids (Uchida et al. 1998, Dang et al. 2001, Kiilerich et al. unpublished data). Our development of a MR antibody functional in IHC made localization of MR in fish tissue possible, showing a similar localization of MR in trout (this study) and salmon gill (Kiilerich et al. unpublished data). The ubiquitous distribution of MR in many gill cell types might indicate non-specificity of the MR antibody on the gill tissue, but immunoneutralization of the MR antibody before IHC demonstrates the specificity of the antibody and confirms the distribution. This suggests that MR is not only involved in osmoregulation but may also be involved in other physiological processes in the gill, such as proliferation and differentiation of cells, acid-base regulation, and respiration.

\section{Co-localization of GR1 and MR in intestine and kidney}

This study is also the first to clearly demonstrate the localization of MR protein in the intestine and kidney showing a ubiquitous distribution among different cell types similar to the pattern observed in gill. The physiological or molecular significance of these data still needs further investigation but supports the probable involvement of this receptor in trout osmoregulation as suggested from $M R$ mRNA regulation in the same osmoregulatory tissue as discussed earlier. The localization of GR1 in the intestine shown in this study is in good agreement with the localization shown in tilapia (Oreochromis mossambicus) posterior intestine (Takahashi et al. 2006a) and sea bass (Dicentrarchus labrax) intestine (Vazzana et al. 2008). In agreement with these data obtained in fish, co-localization of GR and MR has previously been shown in the mammalian kidney and intestine (Farman et al. 1991, Whorwood et al. 1993).

\section{Differential functions of the GR isoforms in trout osmoregulation}

Analysis of GR1 and GR2 mRNA levels in osmoregulatory tissues following salinity transfer overall confirms the involvement of these corticosteroid receptors in salinity acclimation and agrees with the major role of cortisol as a key hormone in activating these signaling pathways. Based on the difference in transactivation activity between GR1 and GR2 (Bury et al. 2003), it is tempting to speculate on differential roles of these two receptors in fish. In this study, both transcripts are overall similarly regulated during both FW-SW and SW-FW acclimation (except kidney and intestine, SW-FW), but differential roles for GR1 and GR2 still need to be considered. However, as the transcription levels given in this study are not supported by protein data, some caution has to be given to this interpretation.

Gill In this study there is an effect of FW-SW transfer on gill GR2 transcript levels in trout. Taken together with the lower $\mathrm{EC}_{50}$ value of GR2 compared with GR1, this indicates an osmoregulatory role of GR2. Nevertheless, it should be noted that Yada et al. (2008) reported an increase in GR2 transcript levels in SW-acclimated trout compared with FW-acclimated trout and Kiilerich et al. (unpublished data) did not observe any changes in gill GR2 levels during FW-SW acclimation in salmon. Taken together with an up-regulation of GR2 mRNA level during SW-FW transfer in this study, it is impossible to reach any conclusion on GR2 function at this point. The downregulation of GR1 presented in this study is in contrast to the FW-SW acclimatory role of GR1 suggested by the up-regulation of GR1 in gill during FW-SW acclimation in Atlantic salmon (Kiilerich et al. 2007b, Nilsen et al. 2008, Kiilerich et al. unpublished data) and during the preparatory development of SW tolerance, smoltification (Mazurais et al. 1998, Mizuno et al. 2001, Kiilerich et al. 2007b). Interestingly, the up-regulation of GR1 transcript level in the gill after SW-FW transfer presented in this study suggests a role for GR1 in FW-acclimation. The reason for this discrepancy is unknown and could be due to species differences between salmon and trout, but the need for more investigations on this matter is obvious.

Intestine Reports on regulation of GRs in the intestine are very few and scattered between different fish species. Furthermore, the lack of knowledge about the GR isoform 
investigated further clouds up this discussion. Tomy et al. (2009) showed an early transient up-regulation of GR mRNA (probably GR2, when phylogenetically compared with other fish GR1 and GR2 sequences known, not shown) at day 1 but not at day 4 after FW-SW transfer of black porgy (Acanthopagrus schlegeli). Takahashi et al. (2006a) showed up-regulation of GR mRNA (probably GR2) at day 7 but not at day 1 after FW-SW transfer in the posterior intestine of tilapia. In this study we did not observe regulation of either GR1 or GR2 in the intestine when trout are transferred from FW to SW but a decrease in GR1 after SW-FW transfer. The reasons for these discrepancies are unknown and might stem from differences in acclimation strategy and physiology between the species investigated. A few indications suggest that the glucocorticoid axis is active in intestinal osmoregulation. Cortisol stimulated both apoptosis and cell proliferation in the anterior intestinal epithelium in FW-SW-transferred mudskipper - two opposite processes connected with intestinal fluid uptake in SW and FW adaptation respectively - whereas DOC had no effect (Takahashi et al. 2006b). Furthermore, cortisol treatment results in an increase in the intestinal fluid uptake in Atlantic salmon and brown trout (Salmo trutta; Veillette et al. 1995, Seidelin et al. 1999), while the intestinal fluid uptake decreased upon RU486 treatment (Veillette et al. 1995) - unfortunately, the effect of spironolactone has not been investigated.

Kidney As in the intestine, information on GR isoform regulation in kidney is more than scarce. The lack of regulation of GR1 and GR2 after FW-SW transfer is in disagreement with the up-regulation of both transcripts in $\mathrm{SW}$-acclimated trout compared with $\mathrm{FW}$-acclimated trout reported by Yada et al. (2008). However, FW-SW transfer of black porgy did not affect GR mRNA (probably GR2, Tomy et al. 2009). Although in this study we show an up-regulation of GR2 levels in kidney during SW-FW acclimation, Tomy et al. (2009) reported a down-regulation of GR mRNA in black porgy (again probably GR2). All in all, there is no good evidence pointing to differential function of the two GR isoforms in fish kidney at this moment.

\section{Conclusion}

Based on this extensive analysis of MR in osmoregulatory tissues during acclimation of trout to SW or FW, where we show localization of MR in the most important osmoregulatory tissues and cell types and salinity- and tissue-specific changes in MR expression in these osmoregulatory organs, we propose a role for MR in osmoregulation. This study suggests a regulatory role of $\mathrm{MR}$ in the kidney and intestine during FW-SW acclimation and in the kidney and gill during SW-FW acclimation. These conclusions are in agreement with regulation of MR in gill during salinity adaptation, which have already been observed by other researchers, although these regulations do not always move in the same direction perhaps due to seasonal, sampling or species-specific differences.
On the other hand, the lack of regulation of DOC plasma levels during salinity acclimation shown in this study and the lack of effect on expression of classical osmoregulatory ion transporters in gill suggest that DOC is not a major regulator of the MR signaling system during rainbow trout salinity acclimation. On the other hand, this study confirms the major osmoregulatory role of cortisol in rainbow trout salinity acclimation through specific activation of the GR signaling system as shown by the in vitro effects of cortisol. Thus, the possibility that cortisol might be the physiological ligand for MR during salinity acclimation has to be considered.

\section{Declaration of interest}

The authors declare that there is no conflict of interest that could be perceived as prejudicing the impartiality of the research project.

\section{Funding}

P K was supported by a postdoctoral grant from the Danish National Research Council (09-065881).

\section{References}

Auperin B, Baroiller JF, Ricordel MJ, Fostier A \& Prunet P 1997 Effect of confinement stress on circulating levels of growth hormone and two prolactins in freshwater-adapted tilapia (Oreochromis niloticus). General and Comparative Endocrinology 108 35-44. (doi:10.1006/gcen.1997.6938)

Bosworth N \& Towers P 1989 Scintillation proximity assay. Nature 341 167-168. (doi:10.1038/341167a0)

Bury NR, Sturm A, Le Rouzic P, Lethimonier C, Ducouret B, Guiguen Y, Robinson-Rechavi M, Laudet V, Rafestin-Oblin ME \& Prunet P 2003 Evidence for two distinct functional glucocorticoid receptors in teleost fish. Journal of Molecular Endocrinology 31 141-156. (doi:10.1677/jme.0.0310141) Campbell CM, Walsh JM \& Idler DR 1976 Steroids in the plasma of the winter flounder (Pseudopleuronectes americanus Walbaum). A seasonal study and investigation of steroids involvement in oocyte maturation. General and Comparative Endocrinology 29 14-20. (doi:10.1016/0016-6480(76)90002-2)

Campbell CM, Fostier A, Jalabert B \& Truscott B 1980 Identification and quantification of steroids in the serum of rainbow trout during spermiation and oocyte maturation. Journal of Endocrinology 85 371-378. (doi:10.1677/ joe.0.0850371)

Dang Z, Balm PH, Flik G, Wendelaar Bonga SE \& Lock RA 2000 Cortisol increases $\mathrm{Na}^{+} / \mathrm{K}^{+}$-ATPase density in plasma membranes of gill chloride cells in the freshwater tilapia Oreochromis mossambicus. Journal of Experimental Biology 203 2349-2355.

Dang ZC, Berntssen MHG, Lundebye AK, Flik G, Wendelaar Bonga SE \& Lock RAC 2001 Metallothionein and cortisol receptor expression in gills of Atlantic salmon, Salmo salar, exposed to dietary cadmium. Aquatic Toxicology 53 91-101. (doi:10.1016/S0166-445X(00)00168-5)

Ducouret B, Tujague M, Ashraf J, Mouchel N, Servel N, Valotaire Y \& Thompson EB 1995 Cloning of a teleost fish glucocorticoid receptor shows that it contains a deoxyribonucleic acid-binding domain different from that of mammals. Endocrinology 136 3774-3783. (doi:10.1210/en.136.9.3774)

Evans DH, Piermarini PM \& Choe KP 2005 The multifunctional fish gill: dominant site of gas exchange, osmoregulation, acid-base regulation, and excretion of nitrogenous waste. Physiological Reviews 85 97-177. (doi:10. 1152/physrev.00050.2003)

Farman N \& Rafestin-Oblin ME 2001 Multiple aspects of mineralocorticoid selectivity. American Journal of Physiology. Renal Physiology 280 F181-F192. 
Farman N, Oblin ME, Lombes M, Delahaye F, Westphal HM, Bonvalet JP \& Gasc JM 1991 Immunolocalization of gluco- and mineralocorticoid receptors in rabbit kidney. American Journal of Physiology. Cell Physiology 260 C226-C233.

Fiet J 1979 Mise au point de dosage radioimmunologique de stéroïdes plasmatiques. Application à l'étude de l'hyperplasie congénitale de surrénales et des hirsutismes. PhD Thesis. René Descartes University, Pharmacology Department.

Fiet J, Giton F, Fidaa I, Valleix A, Galons H \& Raynaud JP 2004 Development of a highly sensitive and specific new testosterone time-resolved fluoroimmunoassay in human serum. Steroids 69 461-471. (doi:10.1016/ j.steroids.2004.04.008)

Greenwood AK, Butler PC, White RB, DeMarco U, Pearce D \& Fernald RD 2003 Multiple corticosteroid receptors in a teleost fish: distinct sequences, expression patterns, and transcriptional activities. Endocrinology 144 4226-4236. (doi:10.1210/en.2003-0566)

Holmes WN 1959 Studies on the hormonal control of sodium metabolism in the rainbow trout (Salmo gairdneri). Acta Endocrinologica 31 587-602. (doi:10.1530/acta.0.XXXI0587)

Jiang JQ, Young G, Kobayashi T \& Nagahama Y 1998 Eel (Anguilla japonica) testis 11beta-hydroxylase gene is expressed in interrenal tissue and its product lacks aldosterone synthesizing activity. Molecular and Cellular Endocrinology 146 207-211. (doi:10.1016/S0303-7207(98)00147-6)

Jiang JQ, Wang DS, Senthilkumaran B, Kobayashi T, Kobayashi HK, Yamaguchi A, Ge W, Young G \& Nagahama Y 2003 Isolation, characterization and expression of 11beta-hydroxysteroid dehydrogenase type 2 cDNAs from the testes of Japanese eel (Anguilla japonica) and Nile tilapia (Oreochromis niloticus). Journal of Molecular Endocrinology 31 305-315. (doi:10.1677/jme.0.0310305)

Katz Y \& Eckstein B 1974 Changes in steroid concentration in blood of female Tilapia aurea (teleostei, cichlidae) during initiation of spawning. Endocrinology 95 963-967. (doi:10.1210/endo-95-4-963)

Kiilerich P, Kristiansen K \& Madsen SS 2007a Cortisol regulation of ion transporter mRNA in Atlantic salmon gill and the effect of salinity on the signaling pathway. Journal of Endocrinology 194 417-427. (doi:10.1677/JOE07-0185)

Kiilerich P, Kristiansen K \& Madsen SS $2007 b$ Hormone receptors in gills of smolting Atlantic salmon, Salmo salar: expression of growth hormone, prolactin, mineralocorticoid and glucocorticoid receptors and 11 betahydroxysteroid dehydrogenase type 2. General and Comparative Endocrinology 152 295-303. (doi:10.1016/j.ygcen.2006.12.018)

Kiilerich P, Pedersen SH, Kristiansen K \& Madsen SS 2011 Corticosteroid regulation of $\mathrm{Na}^{+}, \mathrm{K}^{+}$-ATPase [alpha]1-isoform expression in Atlantic salmon gill during smolt development. General and Comparative Endocrinology 170 283-289. (doi:10.1016/j.ygcen.2010.02.014)

Kusakabe M, Nakamura I \& Young G 200311 \{beta\}-Hydroxysteroid dehydrogenase complementary deoxyribonucleic acid in rainbow trout: cloning, sites of expression, and seasonal changes in gonads. Endocrinology 144 2534-2545. (doi:10.1210/en.2002-220446)

Marshall WS \& Grosell M 2006 Ion transport, osmoregulation and acid-base balance. In The Physiology of Fishes, 3rd edn, pp 177-230. Eds DH Evans \& JB Claiborne. Boca Raton: CRC Press.

Mazurais D, Ducouret B, Tujague M, Valotaire Y, D'Cotta H, Gallais C \& Prunet P 1998 Regulation of the glucocorticoid receptor mRNA levels in the gills of Atlantic salmon (Salmo salar) during smoltification. Bulletin Francais de la Peche et de la Pisciculture 350-351 499-510. (doi:10.1051/ kmae:1998019)

McCormick SD 2001 Endocrine control of osmoregulation in teleost fish American Zoologist 41 781-794. (doi:10.1668/0003-

1569(2001)041[0781:ECOOIT]2.0.CO;2)

McCormick SD, Dickhoff WW, Duston J, Nishioka RS \& Bern HA 1991 Developmental differences in the responsiveness of gill $\mathrm{Na}^{+}, \mathrm{K}(+)$-ATPase to cortisol in salmonids. General and Comparative Endocrinology 84 308-317. (doi:10.1016/0016-6480(91)90054-A)

McCormick SD, Regish A, O’Dea MF \& Shrimpton JM 2008 Are we missing a mineralocorticoid in teleost fish? Effects of cortisol, deoxycorticosterone and aldosterone on osmoregulation, gill $\mathrm{Na}^{+}, \mathrm{K}^{+}$-ATPase activity and isoform mRNA levels in Atlantic salmon General and Comparative Endocrinology 157 35-40. (doi:10.1016/j.ygcen.2008.03.024)

Milla S, Jalabert B, Rime H, Prunet P \& Bobe J 2006 Hydration of rainbow trout oocyte during meiotic maturation and in vitro regulation by 17,20\{beta \}-dihydroxy-4-pregnen-3-one and cortisol. Journal of Experimental Biology 209 1147-1156. (doi:10.1242/jeb.02094)

Milla S, Terrien X, Sturm A, Ibrahim F, Giton F, Fiet J, Prunet P \& Le GF 2008 Plasma 11-deoxycorticosterone (DOC) and mineralocorticoid receptor testicular expression during rainbow trout Oncorhynchus mykiss spermiation: implication with 17alpha, 20beta-dihydroxyprogesterone on the milt fluidity? Reproductive Biology and Endocrinology 6 19. (doi:10.1186/ 1477-7827-6-19)

Mizuno S, Ura K, Onodera Y, Fukada H, Misaka N, Hara A, Adachi S \& Yamauchi K 2001 Changes in transcript levels of gill cortisol receptor during smoltification in wild masu salmon, Oncorhynchus masou. Zoological Science 18 853-860. (doi:10.2108/zsj.18.853)

Mommsen TP, Vijayan MM \& Moon TW 1999 Cortisol in teleosts: dynamics, mechanisms of action, and metabolic regulation. Reviews in Fish Biology and Fisheries 9 211-268. (doi:10.1023/A:1008924418720)

Nilsen TO, Ebbesson LO, Kiilerich P, Bjornsson BT, Madsen SS, McCormick SD \& Stefansson SO 2008 Endocrine systems in juvenile anadromous and landlocked Atlantic salmon (Salmo salar): seasonal development and seawater acclimation. General and Comparative Endocrinology 155 762-772. (doi:10.1016/j.ygcen.2007.08.006)

Parks SK, Tresguerres M \& Goss GG 2006 Interactions between Na+ channels and $\mathrm{Na}^{+}-\mathrm{HCO}_{3}^{-}$cotransporters in the freshwater fish gill MR cell: a model for transepithelial $\mathrm{Na}+$ uptake. American Journal of Physiology. Cell Physiology 292 C935-C944. (doi:10.1152/ajpcell.00604.2005)

Perry SF \& Gilmour KM 2006 Acid-base balance and $\mathrm{CO}_{2}$ excretion in fish: unanswered questions and emerging models. Respiratory Physiology and Neurobiology 154 199-215. (doi:10.1016/j.resp.2006.04.010)

Prunet P, Sturm A \& Milla S 2006 Multiple corticosteroid receptors in fish: from old ideas to new concepts. General and Comparative Endocrinology 147 17-23. (doi:10.1016/j.ygcen.2006.01.015)

Rashid S \& Lewis GF 2005 The mechanisms of differential glucocorticoid and mineralocorticoid action in the brain and peripheral tissues. Clinical Biochemistry 38 401-409. (doi:10.1016/j.clinbiochem.2004.11.009)

Scott GR, Keir KR \& Schulte PM 2005 Effects of spironolactone and RU486 on gene expression and cell proliferation after freshwater transfer in the euryhaline killifish. Journal of Comparative Physiology. B, Biochemical, Systemic, and Environmental Physiology 175 499-510. (doi:10.1007/s00360-0050014-2)

Seidelin M, Madsen SS, Byrialsen A \& Kristiansen K 1999 Effects of insulin-like growth factor-I and cortisol on $\mathrm{Na}^{+}, \mathrm{K}^{+}$-ATPase expression in osmoregulatory tissues of brown trout (Salmo trutta). General and Comparative Endocrinology 113 331-342. (doi:10.1006/gcen. 1998.7225)

Shrimpton JM \& McCormick SD 1999 Responsiveness of gill $\mathrm{Na}^{+} / \mathrm{K}^{+}{ }_{-}$ ATPase to cortisol is related to gill corticosteroid receptor concentration in juvenile rainbow trout. Journal of Experimental Biology 202 987-995.

Sloman KA, Desforges PR \& Gilmour KM 2001 Evidence for a mineralocorticoid-like receptor linked to branchial chloride cell proliferation in freshwater rainbow trout. Journal of Experimental Biology 204 3953-3961.

Stolte EH, de Mazon AF, Leon-Koosterziel KM, Jesiak M, Bury NR, Sturm A, Savelkoul HF, van Kemenade BM \& Flik G 2008 Corticosteroid receptors involved in stress regulation in common carp, Cyprinus carpio. Journal of Endocrinology 198 403-417. (doi:10.1677/JOE-08-0100)

Sturm A, Bury N, Dengreville L, Fagart J, Flouriot G, Rafestin-Oblin ME \& Prunet P 2005 11-Deoxycorticosterone is a potent agonist of the rainbow trout (Oncorhynchus mykiss) mineralocorticoid receptor. Endocrinology 146 47-55. (doi:10.1210/en.2004-0128)

Takahashi H, Sakamoto T, Hyodo S, Shepherd BS, Kaneko T \& Grau EG $2006 a$ Expression of glucocorticoid receptor in the intestine of a euryhaline teleost, the Mozambique tilapia (Oreochromis mossambicus): effect of seawater exposure and cortisol treatment. Life Sciences 78 2329-2335. (doi:10.1016/ j.lfs.2005.09.050) 
Takahashi H, Takahashi A \& Sakamoto T 2006 b In vivo effects of thyroid hormone, corticosteroids and prolactin on cell proliferation and apoptosis in the anterior intestine of the euryhaline mudskipper (Periophthalmus modestus). Life Sciences 79 1873-1880. (doi:10.1016/j.lfs.2006.06.021)

Teitsma C, Lethimonier C, Tujague M, Anglade I, Saligaut D, Bailhache T, Pakdel F, Kah O \& Ducouret B 1998 Identification of potential sites of cortisol actions on the reproductive axis in rainbow trout. Comparative Biochemistry and Physiology-Part C: Pharmacology, Toxicology and Endocrinology 119 243-249. (doi:10.1016/S0742-8413(98)00013-9)

Tomy S, Chang YM, Chen YH, Cao JC, Wang TP \& Chang CF 2009 Salinity effects on the expression of osmoregulatory genes in the euryhaline black porgy Acanthopagrus schlegeli. General and Comparative Endocrinology 161 123-132. (doi:10.1016/j.ygcen.2008.12.003)

Truscott B, Idler DR, Sundararaj BI \& Goswami SV 1978 Effects of gonadotropins and adenocorticotropin on plasmatic steroids of the catfish, Heteropneustes fossilis (Bloch). General and Comparative Endocrinology 34 149-157. (doi:10.1016/0016-6480(78)90205-8)

Tujague M, Saligaut D, Teitsma C, Kah O, Valotaire Y \& Ducouret B 1998 Rainbow trout glucocorticoid receptor overexpression in Escherichia coli: production of antibodies for western blotting and immunohistochemistry. General and Comparative Endocrinology 110 201-211. (doi:10.1006/gcen. 1998.7066)

Uchida K, Kaneko T, Tagawa M \& Hirano T 1998 Localization of cortisol receptor in branchial chloride cells in chum salmon fry. General and Comparative Endocrinology 109 175-185. (doi:10.1006/gcen.1997.7019)
Vazzana M, Vizzini A, Salerno G, Di Bella ML, Celi M \& Parrinello N 2008 Expression of a glucocorticoid receptor (D1GR1) in several tissues of the teleost fish Dicentrarchus labrax. Tissue and Cell 40 89-94. (doi:10.1016/ j.tice.2007.09.008)

Veillette PA, Sundell K \& Specker JL 1995 Cortisol mediates the increase in intestinal fluid absorption in atlantic salmon during Parr-Smolt transformation. General and Comparative Endocrinology 97 250-258. (doi:10.1006/ gcen.1995.1024)

Whorwood CB, Barber PC, Gregory J, Sheppard MC \& Stewart PM 1993 11 beta-Hydroxysteroid dehydrogenase and corticosteroid hormone receptors in the rat colon. American Journal of Physiology. Endocrinology and Metabolism 264 E951-E957.

Yada T, Hyodo S \& Schreck CB 2008 Effects of seawater acclimation on mRNA levels of corticosteroid receptor genes in osmoregulatory and immune systems in trout. General and Comparative Endocrinology 156 622-627. (doi:10.1016/j.ygcen.2008.02.009)

Received in final form 22 January 2011

Accepted 22 February 2011

Made available online as an Accepted Preprint 22 February 2011 